\title{
Grafting Improves Tomato Salinity Tolerance through Sodium Partitioning within the Shoot
}

\author{
Francesco Di Gioia and Angelo Signore ${ }^{1}$ \\ Dipartimento di Scienze agro-ambientali e territoriali, Università degli Studi \\ di Bari “Aldo Moro," via Amendola 165/A, 70126 Bari, Italy
}

Francesco Serio

Istituto di Scienze delle Produzioni Alimentari, Consiglio Nazionale delle Ricerche, via Amendola 122/O, 70126 Bari, Italy

\section{Pietro Santamaria \\ Dipartimento di Scienze agro-ambientali e territoriali, Università degli Studi di Bari “Aldo Moro," via Amendola 165/A, 70126 Bari, Italy}

\begin{abstract}
Additional index words. rootstock, sodium compartmentation, ionic homeostasis, salt stress, fruit quality
\end{abstract}

\begin{abstract}
Two greenhouse experiments were carried out to analyze the shoot sodium $\left(\mathrm{Na}^{+}\right)$partitioning, yield, and fruit quality of 'Cuore di Bue', a salt-sensitive heirloom tomato (Solanum lycopersicum L.), ungrafted or grafted onto interspecific tomato hybrid rootstocks (S. lycopersicum $\times$ S. habrochaites) 'Maxifort' and 'Arnold' in 2009, 'Arnold' and 'Armstrong' in 2010, grown at different salinity stress (SS) levels (0, 20, and $40 \mathrm{~mm}$ of $\mathrm{NaCl}$ in 2009; 0 and $20 \mathrm{~mm}$ of $\mathrm{NaCl}$ in 2010). In both experiments, an interaction was observed between grafting combinations and SS levels in terms of fruit yield, and fruit juice $\mathrm{Na}^{+}$content. Under no SS conditions, plant grafted onto 'Maxifort' and 'Armstrong' provided the highest yield in 2009 and 2010 experiments, respectively. In the presence of $20 \mathrm{~mm}$ of $\mathrm{NaCl}$, plants grafted onto 'Arnold' provided a marketable yield $\mathbf{2 3 . 5 \%}$ (on average) higher than plants grafted onto 'Maxifort' or ungrafted in 2009 and $33 \%$ (on average) higher than plants grafted onto 'Armstrong' or ungrafted in 2010. The further increase of $\mathrm{SS}$ to $\mathbf{4 0} \mathrm{mm}$ of $\mathrm{NaCl}$ considerably reduced the productivity of all grafting combinations. At $20 \mathrm{~mm}$ of $\mathrm{NaCl}$, plants grafted onto 'Arnold' showed also a higher capacity to modulate shoot $\mathrm{Na}^{+}$partitioning with respect to ungrafted plants by increasing $\mathrm{Na}^{+}$accumulation in older leaves $(52 \%)$ and reducing $\mathrm{Na}^{+}$content in younger and most active leaves $(24 \%)$, thus enabling the maintenance of higher $\mathrm{K}^{+} / \mathrm{Na}^{+}, \mathrm{Ca}^{2+} / \mathrm{Na}^{+}$, and $\mathrm{Mg}^{2+} / \mathrm{Na}^{+}$ratios compared with ungrafted plants. Fruit total soluble solids content, titratable acidity, and dry matter were unaffected by grafting at any SS level, whereas under SS, the fruit juice $\mathrm{Na}^{+}$content of grafted plants was consistently lower (from $19 \%$ up to $68 \%$ ) than that of ungrafted plants. Under moderate $\mathrm{SS}$ conditions (20 mu of $\mathrm{NaCl}$ ), the use of rootstock genotypes such as 'Arnold' having a particular ability to reduce $\mathrm{Na}^{+}$ accumulation in younger and most active leaves may increase tomato yield and enhance tomato nutritional value by reducing the fruit juice $\mathrm{Na}^{+}$content.
\end{abstract}

As the use of tomato grafting is gaining popularity worldwide (Kubota et al., 2008; Lee et al., 2010), breeders and seed companies are eager to select and develop new rootstocks characterized by high yield and fruit quality performance, multidisease resistance (Barrett et al., 2012; Guan et al., 2012; King et al., 2008), and possibly tolerance to

Received for publication 6 Feb. 2013. Accepted for publication 17 May 2013

The research was funded by MIUR-PRIN 2007 and 2009 (Ministry of Education, University and Research, Italy, Projects "Vegetable grafting: Biophysiological basis, effects on crop and product quality" and "Physiological response, growth, yield, and quality of grafted tomato under combined excess boron and salinity stress."

${ }^{1}$ To whom reprint requests should be addressed; e-mail angelo.signore@uniba.it. specific abiotic stress conditions (King et al., 2010; Savvas et al., 2010; Schwarz et al., 2010).

Salinity is one of the most critical environmental stresses that limit agriculture worldwide. Over $20 \%$ of irrigated land is affected by salinity (Rozema and Flowers, 2008), and although arid and semiarid zones are more subject to this phenomenon, salinization is increasingly affecting also less extreme environments being strictly associated with the irrigation practice itself (Tanji and Kielen, 2002).

The detrimental effects of salinity on crops are mainly related to 1) osmotic stress, resulting from the accumulation of high solute concentrations in the rooting zone; 2) ionspecific toxicity, mainly caused by $\mathrm{Na}^{+}$and $\mathrm{Cl}^{-}$; and 3) ion imbalance in cells, especially lower concentration of $\mathrm{K}^{+}, \mathrm{Ca}^{2+}, \mathrm{SO}_{4}{ }^{2-}$, and $\mathrm{NO}_{3}{ }^{-}$(Giuffrida et al., 2009), leading to several physiological and biochemical changes that inhibit plant growth and production and affect the fruit quality (Cuartero and FernandezMuñoz, 1999).

Grafting has been shown to be a valid technique to enhance tomato plant growth and productivity (Colla et al., 2010; Estañ et al., 2005; Fernández-García et al., 2004). Unlike traditional breeding, grafting enables the combination of desired high-yielding and/or high-quality tomato genotypes, often susceptible to SS, with rootstocks characterized by higher vigor and, potentially, capable of improving the scion tolerance to SS conditions (Bolarin et al., 1991; Estañ et al., 2009; Ghanem et al., 2011).

Enhanced tolerance to SS in grafted vegetable crops has mainly been attributed to the $\mathrm{Na}^{+}$exclusion (Edelstein et al., 2011; Estañ et al., 2005) and/or inclusion capacity in the shoot and/or root vacuoles (Albacete et al., 2009; Edelstein et al., 2011). Instead, grafting and/or rootstocks seem to be less effective in restricting and/or regulating $\mathrm{Cl}^{-}$transport and/or concentration in the shoot (Colla et al., 2006; Edelstein et al., 2011; Savvas et al., 2011). Nevertheless, the mechanism of $\mathrm{Na}^{+}$ exclusion and/or inclusion in the shoot/root of grafted plants and the role played by the scion and rootstock genotypes remain still unclear.

In a recent study conducted on melon and pumpkin with reciprocal grafting, Edelstein et al. (2011) attributed the lower $\mathrm{Na}^{+}$concentration observed in plants grafted on pumpkin rootstock mainly to the $\mathrm{Na}^{+}$exclusion and retention by the rootstock, rejecting the hypothesis that 1) $\mathrm{Na}^{+}$transport to the scion can be restricted by grafting itself; and 2) the scion may play a role in $\mathrm{Na}^{+}$partitioning within the plant. However, physiological studies suggest that, in tomato and other solanaceous species, salinity tolerance (ST) is mainly related to a $\mathrm{Na}^{+}$inclusion mechanism (Bolarin et al., 1991; Chen et al., 2003; Pérez-Alfocea et al., 1993) and is closely correlated to the ability of the plant to regulate $\mathrm{Na}^{+}$concentration in the leaf tissue (Cuartero and Fernandez-Muñoz, 1999; Sacher et al., 1983; Savvas et al., 2011) and to maintain a high $\mathrm{K}^{+} / \mathrm{Na}^{+}$ratio. Although maintenance of higher $\mathrm{K}^{+} / \mathrm{Na}^{+}$ratios in grafted plants grown under SS conditions has often been associated with a higher $\mathrm{K}^{+}$ uptake capacity of the rootstock (Albacete et al., 2009; Leonardi and Giuffrida, 2006; Santa-Cruz et al., 2002), $\mathrm{Na}^{+}$partitioning in young and mature leaves represents a key aspect of such regulation (Maggio et al., 2007; Shannon, 1997; Shannon et al., 1987).

In the present study we hypothesized that grafting onto vigorous interspecific hybrids (S. lycopersicum $\times S$. habrochaites) might raise the ST of tomato also through the regulation of $\mathrm{Na}^{+}$partitioning in young and mature leaves. In this regard, a complete analysis of the $\mathrm{Na}^{+}$partitioning within the shoot portions of grafted plants is still missing in the literature and is required for a better comprehension of the rootstock-scion interaction under SS conditions and to also clarify possible effects on fruit $\mathrm{Na}^{+}$content and 
quality (Davis et al., 2008; Rouphael et al., 2010). Although SS may improve the organoleptic quality of tomato fruits, it may also increase the fruit $\mathrm{Na}^{+}$content, causing a loss of nutritional value given the notorious $\mathrm{Na}^{+}$ negative effects on human health (Karppanen and Marvaala, 2006).

Therefore, the objectives of this study were to analyze the shoot $\mathrm{Na}^{+}$partitioning of grafted and ungrafted plants of 'Cuore di Bue', an "oxheart" heirloom tomato type that is characterized by big-sized fruits and considered to be particularly sensitive to SS, and to evaluate the interaction between salinity levels and different commercial tomato rootstocks (claimed to be particularly vigorous and tolerant to SS conditions) in terms of plant $\mathrm{Na}^{+}$content, yield, and fruit quality.

\section{Materials and Methods}

Plant material, treatments, and growth conditions. Two experiments were conducted in Italy during the spring to early summer season (February to July) in 2009 and 2010 at Mola di Bari (lat. $41^{\circ} 03^{\prime} \mathrm{N}$, long. $17^{\circ} 4^{\prime} \mathrm{E}$; $24 \mathrm{~m}$ a.s.1.) in a $680-\mathrm{m}^{2}$ polymethacrylate experimental greenhouse. Nutrient solutions having different $\mathrm{NaCl}$ (commercial salt, $99.9 \%$ purity) concentrations $(0,20$, and $40 \mathrm{~mm}$ in 2009; 0 and $20 \mathrm{~mm}$ in 2010) were applied as salinity treatments to plants of tomato [Solanum lycopersicum (L.), cultivar Cuore di Bue (CB)] ungrafted (control) or grafted onto either of the two interspecific (S. lycopersicum $\times$ $S$. habrochaites) rootstocks: 'Maxifort' (De Ruiter Seeds, Bergschenhoek, The Netherlands) and 'Arnold' (Syngenta Seeds, Greensboro, NC) in 2009; or 'Arnold' and 'Armstrong' (Syngenta Seeds) in 2010.

For both experiments, a split plot with three replicates was used as the experimental design: $\mathrm{NaCl}$ levels in the main plots (rows) and grafting combinations in the subplots. Each experimental unit consisted of seven plants.

Commercial seedlings ungrafted or grafted were produced by a specialized nursery. Rootstock seeds were sown $4 \mathrm{~d}$ before scion seeds on 16 Jan. 2009 and 5 Jan. 2010. Seedlings were grown under protected environment in 112-cell-count polypropylene plug trays. At the two true-leaf stage, rootstock and scion seedlings were grafted with the splice-tube method and held together using 2.1 - or $2.3-\mathrm{mm}$ polyester pipe clips and seedling support sticks (Grafting \& Technology, Passatempo di Osimo, Italy). Grafted and ungrafted seedlings were transplanted at the fourth true-leaf stage, on 26 Feb. 2009 and 15 Feb. 2010, into 10-L polyethylene black pots ( $24 \mathrm{~cm}$ top diameter) containing a perlite-peat substrate mix $(3: 1, \mathrm{v} / \mathrm{v})$ with distances of $1.3 \mathrm{~m}$ between rows and $0.25 \mathrm{~m}$ within the row to establish a density of 3.1 plants $/ \mathrm{m}^{2}$. Pots were placed on $6 \mathrm{~m}$ long $\times 0.26 \mathrm{~m}$ wide $1 \%$ sloped troughs covered by polyethylene film colored black on the underside and white on the upper side. Greenhouse ventilation temperature was $20^{\circ} \mathrm{C}$. In the 2009 experiment, daily air temperature in the greenhouse was on average $21.0^{\circ} \mathrm{C}$, and daily minimum and maximum air temperature ranged from 5.0 to $26.0^{\circ} \mathrm{C}$ and from 19.0 to $38.0^{\circ} \mathrm{C}$, respectively (Fig. $1 \mathrm{~A}$ ). In the 2010 experiment, daily air temperature in the greenhouse was on average $19.5^{\circ} \mathrm{C}$, and daily minimum and maximum air temperature ranged from 4.5 to $22.5^{\circ} \mathrm{C}$ and from 17.6 to $34.8^{\circ} \mathrm{C}$, respectively (Fig. 1B). Daily solar radiation was on average $356 \mathrm{~W} \cdot \mathrm{m}^{-2}$ in 2009 and $353 \mathrm{~W} \cdot \mathrm{m}^{-2}$ in the 2010 experiment. Daily relative humidity was on average $77 \%$ and ranged between a minimum of $51 \%$ and a maximum of $90 \%$.

Plants were trained vertically to one stem around each plastic string using the V-shaped method and were topped at the sixth floral cluster. As required by common commercial practice, binding, lateral stem, and basal leaf pruning operations were carried out on plants. A hive of bumblebees (Bombus terrestris L.) was placed in the greenhouse at full anthesis of the first truss to ensure pollination throughout the growing season. An integrated crop management approach was used to control all major diseases and pests.

Nutrient solution management. In both experiments, the control nutrient solution $(0 \mathrm{~mm}$ of $\mathrm{NaCl})$ was prepared with deionized water and contained: nitrogen $(10 \mathrm{~mm})$, phosphorus $(2 \mathrm{mM})$, potassium $(6 \mathrm{~mm})$, magnesium (2 mM), calcium (3 mM), iron $(20 \mu \mathrm{M})$, manganese $(5 \mu \mathrm{M})$, zinc $(2 \mu \mathrm{M})$, boron $(25 \mu \mathrm{M})$, copper $(0.5 \mu \mathrm{M})$, and molybdenum $(0.1 \mu \mathrm{M})$, resulting in an electrical conductivity (EC) of $1.8 \mathrm{dS} \cdot \mathrm{m}^{-1}$. The saline nutrient solutions had the same composition plus 20 and $40 \mathrm{~mm}$ of $\mathrm{NaCl}$, resulting in an $\mathrm{EC}$ of 3.7 and $5.6 \mathrm{dS} \cdot \mathrm{m}^{-1}$, respectively. When needed the nutrient solution $\mathrm{pH}$ was adjusted to 5.5 using $2 \mathrm{M} \mathrm{H}_{2} \mathrm{SO}_{4}$. In both experiments, starting from the sixth true leaf crop stage, salinity treatments were applied to each grafting combination, in all fertigation events, until the end of each experiment. The nutrient solution was delivered to each trough through drip tapes with pressure-compensated drippers, each with a delivery rate of $8.0 \mathrm{~L} \cdot \mathrm{h}^{-1}$,
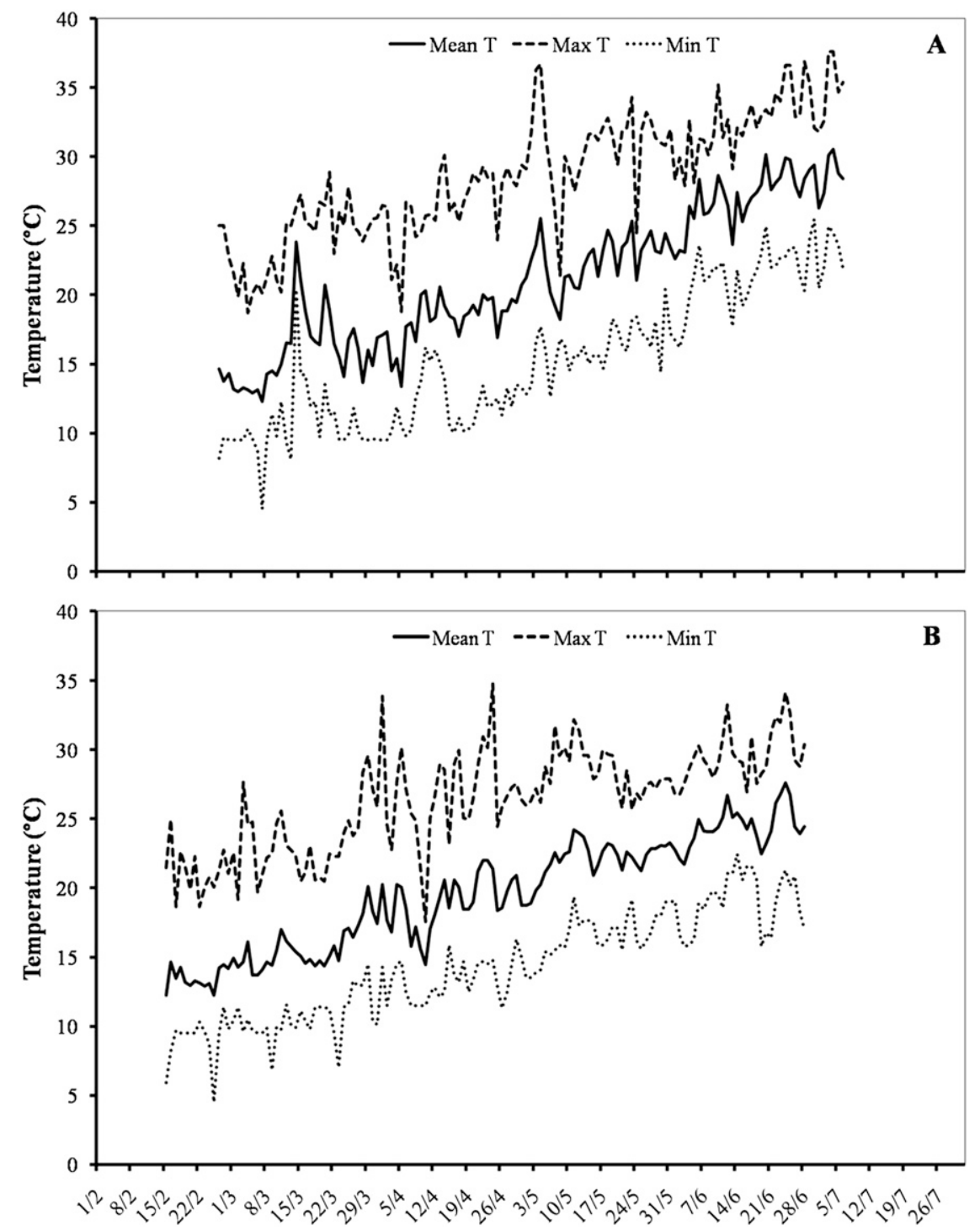

Fig. 1. Mean, maximum and minimum daily air temperature recorded in the greenhouse for 2009 (A) and 2010 (B) experiments. 
spaced $0.05 \mathrm{~m}$ from plants. Fertigation was scheduled equally in all treatment combinations, regulating the number of fertigation events and their duration daily, to maintain a drainage percentage ranging from $20 \%$ up to $60 \%$ to prevent the substrate ion accumulation and large variations of $\mathrm{EC}, \mathrm{pH}$, and $\mathrm{NaCl}$ levels. Drainage was collected and measured for each main plot (salinity treatment) and not reused (open cycle management).

Yields and yield components. Harvests began on 25 May 2009 [88 d after transplanting (DAT)] and 26 May 2010 (100 DAT) and were completed with the harvest of the sixth cluster on 6 July 2009 (130 DAT) and 28 June 2010 (133 DAT), respectively.

Single tomato fruit were harvested at the pink stage $(30 \%$ to $60 \%$ of the fruit surface was pink or red) and classified into marketable or discarded classes according to European Commission Regulation 790/2000 for the marketing standard of tomatoes (Official Journal of the European Communities, L 95, 15 Apr. 2000).

Fruit quality analysis. Total soluble solids (TSS) content, titratable acidity (TA), dry matter (DM), and $\mathrm{Na}^{+}$content were assessed on representative samples of three to four fruits per treatment, picked on 28 May and 25 June (91 and 119 DAT) in 2009, and on 8 and 21 June (113 and 126 DAT) in 2010. A juice sample was obtained by blending and filtering the mesocarp of each fruit. Total soluble solids content was measured using a portable refractometer (Brix-Stix BX 100 Hs; Techniquip Corporation, Livermore, $\mathrm{CA}$ ) and values were expressed in ${ }^{\circ}$ Brix at $20{ }^{\circ} \mathrm{C}$. Titratable acidity was determined by potentiometric titration of $10 \mathrm{~mL}$ of tomato juice to $\mathrm{pH}$
8.1 using $0.1 \mathrm{M} \mathrm{NaOH}$ in the presence of phenolphthalein using a digital burette (Technotrate; Kartell, Milan, Italy). Results were expressed as percentage of citric acid equivalents in the juice. For each tomato fruit sample, $\approx 200 \mathrm{~g}$ of fresh fruits were dried in a forced-air oven at $65{ }^{\circ} \mathrm{C}$ until reaching a constant mass, then weighed to calculate the fruit DM content. Sodium content was measured on tomato juice by ion chromatography (Dionex Model DX500; Dionex Corporation, Sunnyvale, CA) with a conductivity detector using the pre-column IonPack CG12A and the column of separation IonPack CS12A.

Ion partitioning analysis. In 2010, the ion partitioning within the shoot was assessed by sampling and analyzing the ion $\left(\mathrm{Na}^{+}, \mathrm{K}^{+}\right.$, $\mathrm{Ca}^{2+}$, and $\mathrm{Mg}^{2+}$ ) concentration of different shoot portions in three subsequent dates as described hereafter. On 20 Apr. 2010 (64 DAT), three plants per treatment (one for each replication) were sampled and analyzed. Every plant was divided into stem and leaves, and the latter were subdivided in bottom, middle, and upper leaves. On 19 May 2010 (93 DAT), in correspondence with the leaf pruning and plant topping, pruned bottom leaf and plant tip (top plant shoot constituted by four to five leaves above the sixth inflorescence developed) samples were collected separately for each treatment and replication and analyzed. On 21 June 2010 (126 DAT), mature fruits were sampled from each experimental plot to determine ion concentrations $\left(\mathrm{Na}^{+}, \mathrm{K}^{+}, \mathrm{Ca}^{2+}\right.$, and $\left.\mathrm{Mg}^{2+}\right)$.

Plant material of the different shoot portions sampled was dried in a thermo-ventilated oven at $65^{\circ} \mathrm{C}$ until reaching a constant mass and finely ground through a mill (IKA; Labortechnik, Staufen, Germany) with a 1.0-mm sieve. Cations $\left(\mathrm{Na}^{+}, \mathrm{K}^{+}, \mathrm{Ca}^{2+}\right.$, and $\mathrm{Mg}^{2+}$ ) were extracted from 2-g samples of plant tissue DM, ashed in a muffle furnace at $450{ }^{\circ} \mathrm{C}$, digested with $1 \mathrm{M} \mathrm{HCl}$ in a boiling water bath for $30 \mathrm{~min}$, and measured by ion chromatography (Dionex DX120; Dionex Corporation) with a conductivity detector using an IonPack CG12A pre-column and IonPack CS12A separation column for cations.

Statistical analysis. Data were analyzed separately for each experiment by two-way analysis of variance using the GLM procedure in SAS Version 9.1 software (SAS Institute, Cary, NC). All means were compared using Duncan's multiple range test at $P=0.05$.

\section{Results}

Yield and yield components. In both experiments total and marketable fruit number were unaffected by grafting, whereas it decreased with increasing the SS level (Table 1). An interaction was observed for both total and marketable yield (Fig. 2) between grafting combinations and salt treatments, revealing a different response of each grafting combination to increasing SS levels. Figures 2 and 3 report the marketable yield data of 2009 and 2010, respectively, whereas total yield data having a similar trend were not shown. In 2009 (Fig. 2), under no SS conditions, plants grafted onto 'Maxifort' provided a marketable yield $43.7 \%$ and $23.2 \%$ higher than that observed in ungrafted plants or in those grafted onto 'Arnold', respectively. Instead, in the presence of $20 \mathrm{~mm}$ of $\mathrm{NaCl}$, plants

Table 1. Effects of salinity level and grafting combinations on yield components of 'Cuore di Bue' tomato plants in 2009 and 2010 experiments. ${ }^{\mathrm{z}}$

\begin{tabular}{|c|c|c|c|c|c|c|c|}
\hline & $\begin{array}{l}\text { Total yield } \\
\text { (kg/plant) }\end{array}$ & $\begin{array}{l}\text { Marketable yield } \\
(\mathrm{kg} / \text { plant })\end{array}$ & $\begin{array}{l}\text { Unmarketable yield } \\
\text { (kg/plant) }\end{array}$ & $\begin{array}{l}\text { Total fruit } \\
\text { number } \\
\text { (no./plant) }\end{array}$ & $\begin{array}{l}\text { Marketable } \\
\text { fruit number } \\
\text { (no./plant) }\end{array}$ & $\begin{array}{l}\text { Unmarketable } \\
\text { fruit number } \\
\text { (no./plant) }\end{array}$ & $\begin{array}{l}\text { Mean fruit wt } \\
\text { (kg fruit) }\end{array}$ \\
\hline & & & 2009 & & & & \\
\hline \multicolumn{8}{|l|}{$\mathrm{NaCl}(\mathrm{mm})$} \\
\hline 0 & $5.63 \mathrm{a}$ & $5.00 \mathrm{a}$ & 0.63 & $21.8 \mathrm{a}$ & $18.0 \mathrm{a}$ & $3.83 \mathrm{~b}$ & 0.28 \\
\hline 20 & $4.36 \mathrm{~b}$ & $3.78 \mathrm{~b}$ & 0.59 & $21.0 \mathrm{a}$ & $16.9 \mathrm{a}$ & $4.06 \mathrm{~b}$ & 0.24 \\
\hline 40 & $3.26 \mathrm{c}$ & $2.43 \mathrm{c}$ & 0.82 & $15.9 \mathrm{~b}$ & $8.5 \mathrm{~b}$ & $7.36 \mathrm{a}$ & 0.36 \\
\hline \multicolumn{8}{|l|}{ Grafting combination } \\
\hline Arnold & 4.47 & $3.86 \mathrm{a}$ & 0.61 & 19.6 & 15.1 & 4.50 & 0.27 \\
\hline Maxifort & 4.53 & $3.94 \mathrm{a}$ & 0.59 & 21.0 & 16.8 & 4.19 & 0.24 \\
\hline Ungrafted & 4.24 & $3.41 \mathrm{~b}$ & 0.84 & 18.2 & 11.6 & 6.56 & 0.37 \\
\hline \multicolumn{8}{|l|}{ Significance } \\
\hline $\mathrm{NaCl}$ & $* * *$ & $* * *$ & NS & $* *$ & $* *$ & $*$ & NS \\
\hline Grafting combination & NS & $* *$ & NS & NS & NS & NS & NS \\
\hline $\mathrm{NaCl} \times$ grafting combination & $* * *$ & $* * *$ & NS & NS & NS & NS & NS \\
\hline & & & 2010 & & & & \\
\hline \multicolumn{8}{|l|}{$\mathrm{NaCl}(\mathrm{mm})$} \\
\hline 0 & $5.76 \mathrm{a}$ & $5.65 \mathrm{a}$ & 0.11 & $26.4 \mathrm{a}$ & $25.8 \mathrm{a}$ & 0.56 & $0.22 \mathrm{a}$ \\
\hline 20 & $4.31 \mathrm{~b}$ & $4.22 \mathrm{~b}$ & 0.09 & $24.3 \mathrm{~b}$ & $23.7 \mathrm{~b}$ & 0.61 & $0.18 \mathrm{~b}$ \\
\hline \multicolumn{8}{|l|}{ Grafting combination } \\
\hline Armstrong & 4.99 & 4.92 & $0.07 \mathrm{~b}$ & 25.3 & 24.9 & $0.43 \mathrm{~b}$ & 0.20 \\
\hline Arnold & 5.35 & 5.34 & $0.02 \mathrm{~b}$ & 25.6 & 25.4 & $0.13 \mathrm{~b}$ & 0.21 \\
\hline Ungrafted & 4.78 & 4.55 & $0.23 \mathrm{a}$ & 25.1 & 23.9 & $1.19 \mathrm{a}$ & 0.19 \\
\hline \multicolumn{8}{|l|}{ Significance } \\
\hline $\mathrm{NaCl}$ & $* *$ & $* *$ & NS & $*$ & $*$ & NS & $*$ \\
\hline Grafting combination & NS & NS & $* *$ & NS & NS & $*$ & NS \\
\hline $\mathrm{NaCl} \times$ grafting combination & $*$ & $*$ & NS & NS & NS & NS & NS \\
\hline
\end{tabular}

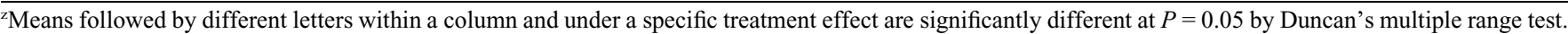
NS, *,** Nonsignificant or significant at $P \leq 0.05$ or 0.01 , respectively. 


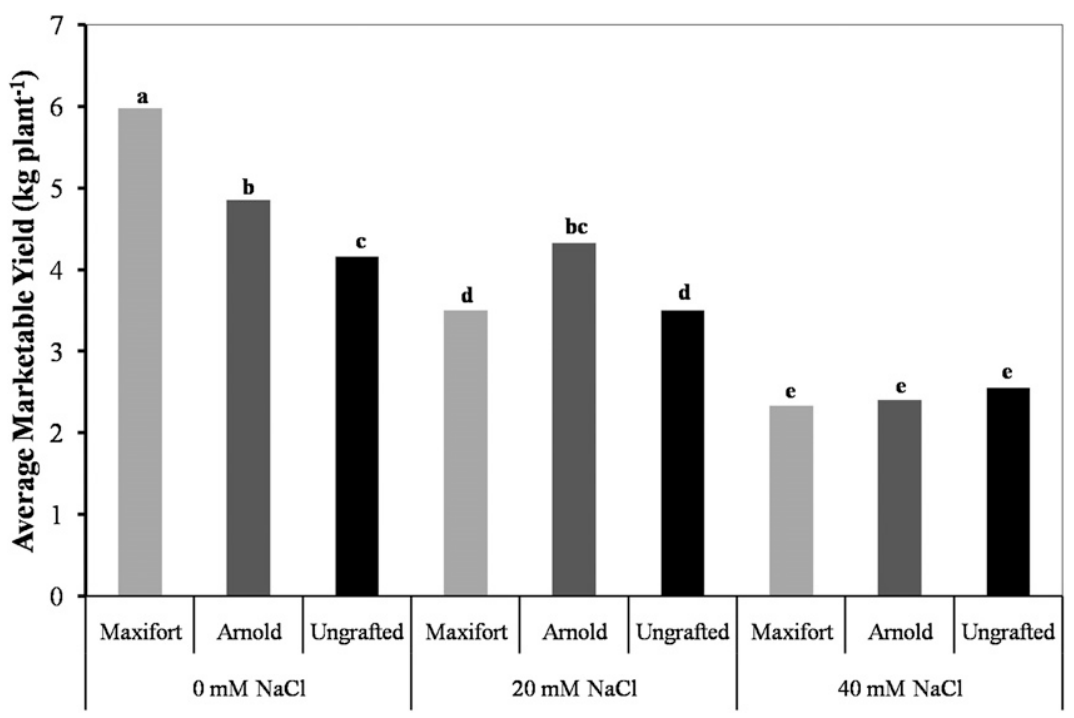

Fig. 2. Effects of salinity level and grafting combinations on marketable yield of 'Cuore di Bue' tomato plants in the 2009 experiment. Different letters indicate significant differences at $P=0.05$ by Duncan's multiple range test.

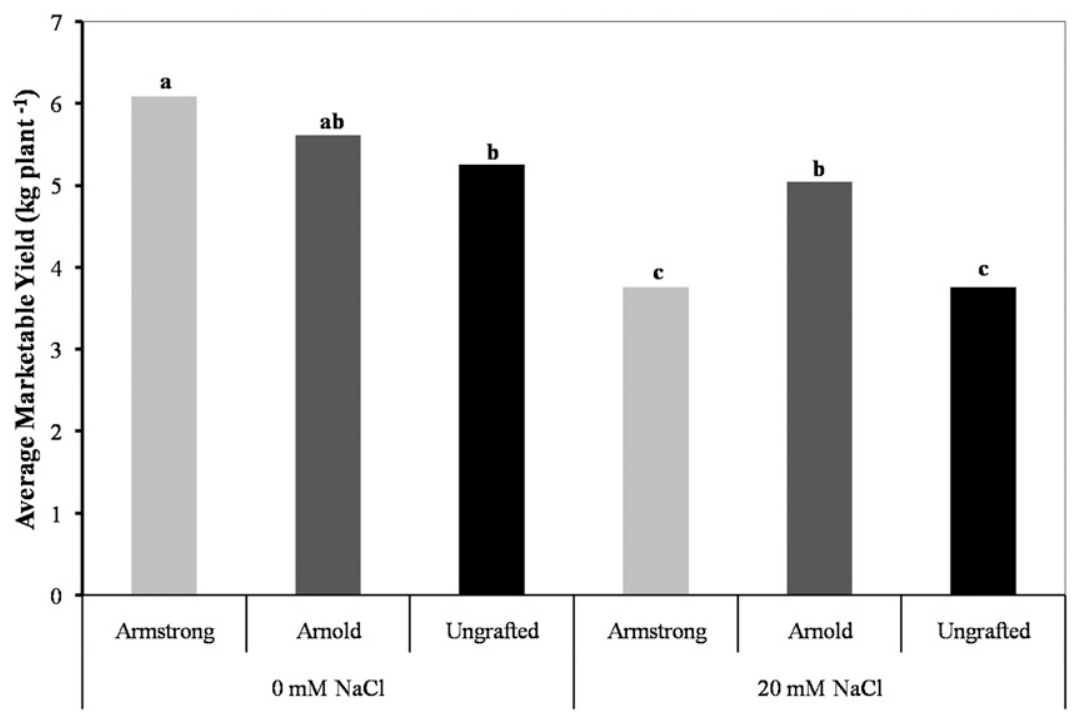

Fig. 3. Effects of salinity level and grafting combinations on marketable yield of 'Cuore di Bue' tomato plants in the 2010 experiment. Different letters indicate significant differences at $P=0.05$ by Duncan's multiple range test.

grafted onto 'Arnold' provided a marketable yield $23.5 \%$ higher than that of plants grafted onto 'Maxifort' or ungrafted. The further increase of SS at levels of $40 \mathrm{~mm}$ of $\mathrm{NaCl}$ considerably reduced the productivity of all grafting combinations, resulting in an average marketable yield of $2.43 \mathrm{~kg} /$ plant without differences among the grafting combinations tested.

Similarly, the second year (Fig. 3), in absence of SS, plants grafted onto 'Armstrong' provided a marketable yield $15.8 \%$ higher than that obtained by ungrafted plants, whereas in the presence of $20 \mathrm{~mm}$ of $\mathrm{NaCl}$, plants grafted onto 'Arnold' provided a marketable yield $34.3 \%$ higher than that of plants grafted onto 'Armstrong' or ungrafted.

Fruit quality and $\mathrm{Na}^{+}$content analysis. Fruit quality parameters such as TSS content, the fruit juice $\mathrm{Na}^{+}$content was unaffected by grafting or rootstock genotype, whereas in the presence of $\mathrm{NaCl}$ stress, the fruit juice $\mathrm{Na}^{+}$content of grafted plants was always lower than that of fruits of ungrafted plants, consistently in all harvesting dates and in both years (Figs. 4 and 5). In more detail, under moderate $\mathrm{SS}$ levels $(20 \mathrm{~mm}$ of $\mathrm{NaCl})$, grafted plants showed on average a fruit juice $\mathrm{Na}^{+}$content $51.1 \%$ and $19.8 \%$ lower than that of ungrafted plants in the first harvesting date of 2009 and 2010 experiments, respectively (Figs. 4A and 5A) and $30.9 \%$ and $42.7 \%$ lower than that of ungrafted plants in the second harvesting date of 2009 and 2010 experiments, respectively (Figs. 4B and 5B). Similarly, in the presence of $40 \mathrm{~mm}$ of $\mathrm{NaCl}$, grafted plants showed on average a fruit juice $\mathrm{Na}^{+}$content from $58.4 \%$ and $48.3 \%$ lower than that of ungrafted plants in the first and second harvesting dates of the 2009 experiment, respectively (Fig. 4A-B).

Shoot $\mathrm{Na}^{+}, \mathrm{K}^{+}, \mathrm{Mg}^{2+}$, and $\mathrm{Ca}^{2+}$ partitioning under salt stress conditions. In 2010, grafted and ungrafted plants grown under SS conditions $(20 \mathrm{~mm} \mathrm{NaCl})$ showed a different $\mathrm{Na}^{+}$ content and partitioning within the different shoot portions analyzed; on average, upper leaves, plant tips, and fruit $\mathrm{Na}^{+}$contents of grafted plants were $21 \%, 50 \%$, and $45 \%$ lower than that of the counterparts of ungrafted plants, respectively (Table 3); vice versa, the $\mathrm{Na}^{+}$contents of pruned and bottom leaves were $14 \%$ and $52 \%$ higher in plants grafted onto 'Arnold' than in ungrafted ones, whereas $\mathrm{Na}^{+}$content of bottom and pruned leaves of plants grafted onto 'Armstrong' were not different from that of plants grafted onto 'Arnold' or ungrafted (Table 3), yet stem and middle leaf $\mathrm{Na}^{+}$contents were not different in grafted and ungrafted plants (Table 3 ).

On average, upper leaves of grafted plants showed $\mathrm{Mg}^{2+}$ and $\mathrm{Ca}^{2+}$ content $31 \%$ and $40 \%$ higher than that of ungrafted plants, respectively. Similarly, the $\mathrm{Mg}^{2+}$ and $\mathrm{Ca}^{2+}$ content of grafted plant tips was $13 \%$ and $27 \%$ higher than those of ungrafted plants, respectively. Conversely, $\mathrm{K}^{+}$content of bottom leaves pruned 93 DAT was on average 23\% lower in grafted plants with respect to ungrafted ones (Table 3 ).

Overall, grafted plants showed a higher $\mathrm{K}^{+} / \mathrm{Na}^{+}, \mathrm{Mg}^{2+} / \mathrm{Na}^{+}$, and $\mathrm{Ca}^{2+} / \mathrm{Na}^{+}$ratio in fruits, plant tips, and upper leaves as compared with ungrafted plants (Table 3). Furthermore, the plant tips of plants grafted onto 'Armstrong' showed $\mathrm{K}^{+} / \mathrm{Na}^{+}$and $\mathrm{Mg}^{2+} / \mathrm{Na}^{+}$ ratios $15.6 \%$ and $18.7 \%$ higher, respectively, than those grafted onto 'Arnold'. On the contrary, bottom leaf and pruned leaf $\mathrm{K}^{+} / \mathrm{Na}^{+}$ ratios were on average $33.7 \%$ and $27.4 \%$ lower in grafted plants than in ungrafted ones without any difference between the rootstocks (Table 3 ).

\section{Discussion}

the TA increased $22.7 \%$ when raising the SS level from 0 to $20 \mathrm{~mm}$ of $\mathrm{NaCl}$, only in fruits harvested on 28 May 2009 (Table 2).

Also fruit juice $\mathrm{Na}^{+}$content was affected by an interaction between the grafting combinations and SS levels. In the absence of SS, 
Table 2. Effects of salinity level and grafting combinations on fruit quality of 'Cuore di Bue' tomato in two harvests of 2009 and 2010 experiments. ${ }^{2}$

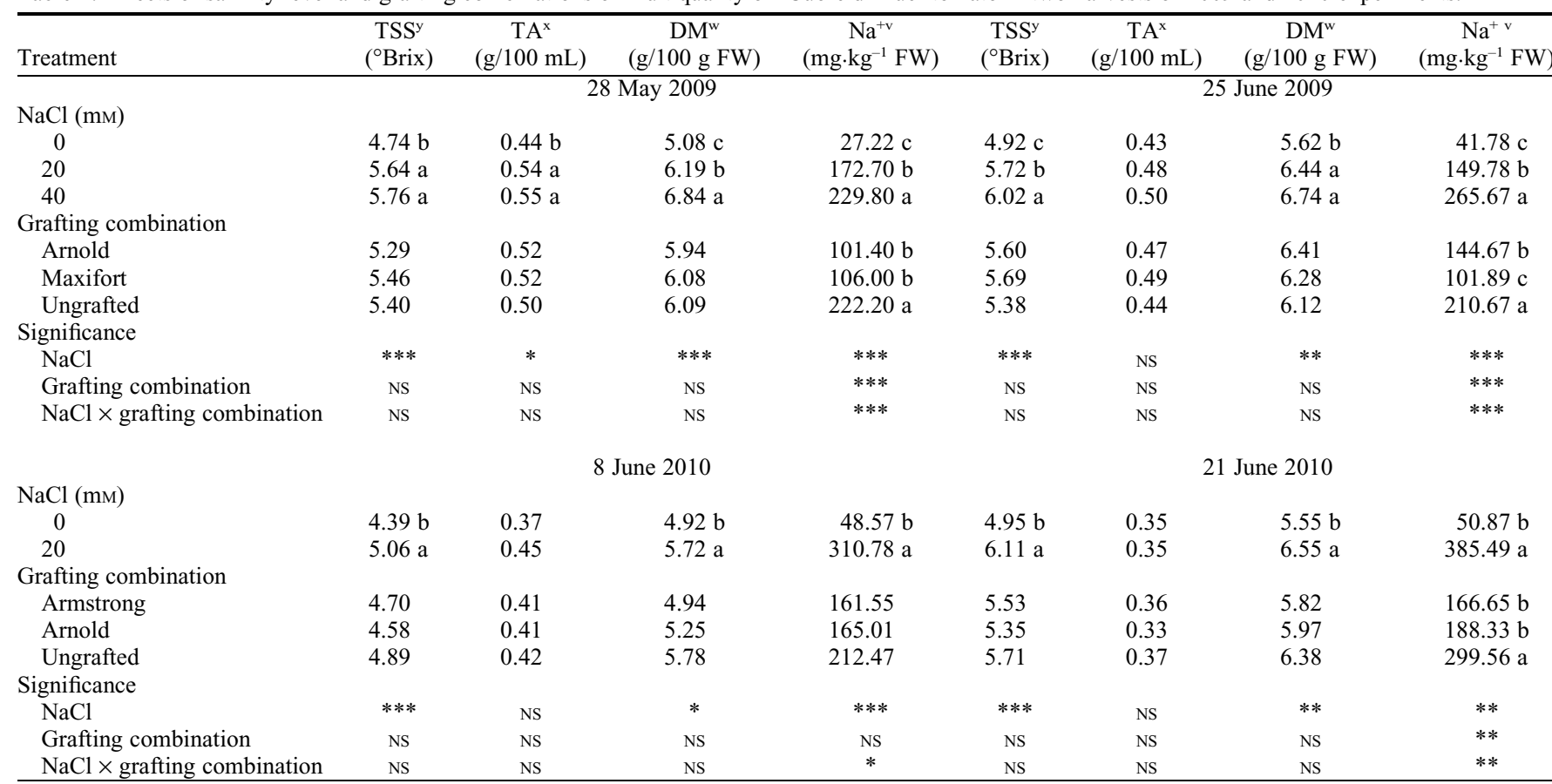

${ }^{2}$ Means followed by different letters within a column and under a specific treatment effect are significantly different at $P=0.05$ by Duncan's multiple range test.

${ }^{y}$ Mean fruit total soluble solids content.

${ }^{\mathrm{x}}$ Mean fruit titratable acidity.

"Mean fruit dry matter.

${ }^{\vee}$ Mean fruit juice $\mathrm{Na}^{+}$content.

NS, ${ }^{*}, * *, * * *$ Nonsignificant or significant at $P \leq 0.05,0.01$, or 0.001 , respectively.

$\mathrm{FW}=$ fresh weight.
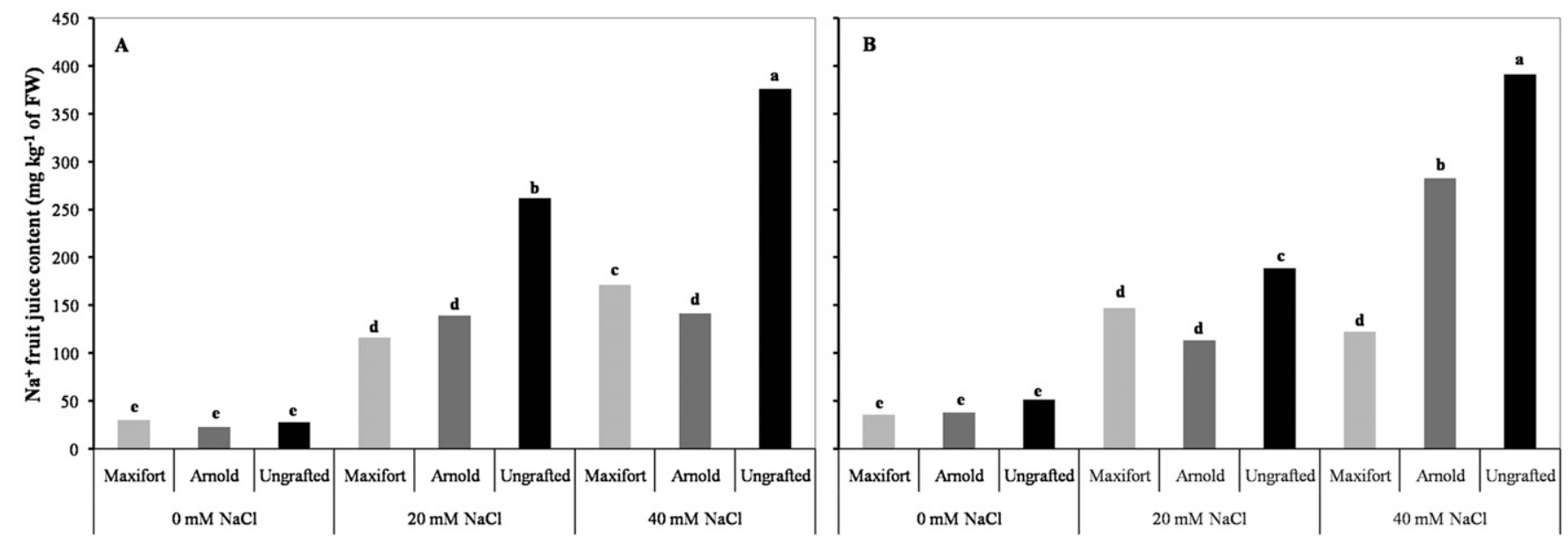

Fig. 4. Effects of salinity level and grafting combinations on the juice $\mathrm{Na}^{+}$content of 'Cuore di Bue' tomato fruits harvested on $28 \mathrm{May} 2009$ (A) and on 25 June 2009 (B). Different letters indicate significant differences at $P=0.05$ by Duncan's multiple range test.

in comparison with ungrafted plants corroborates previous findings (Di Gioia et al., 2010; Khah et al., 2006).

'Cuore di Bue' yield response to SS was consistently modulated by the rootstock genotype, whose role emerged under relatively moderate SS conditions $(20 \mathrm{~mm} \mathrm{NaCl})$, whereas it was nullified in plants grown under more severe $\mathrm{SS}$ conditions ( $40 \mathrm{~mm} \mathrm{NaCl}$ ), suggesting that, at least for big-sized fruit tomato genotypes like the one used in this study, the mechanisms of ST of grafted plants only operate until a certain stress threshold. Such results are in agreement with findings of Savvas et al. (2011) who reported that under SS conditions, the yield response of grafted tomato plants is affected by both rootstock genotype and salinity levels, whereas it is in contrast to the findings of Estañ et al. (2005) and Martinez-Rodriguez et al. (2008), who, working on different rootstock/scion genotypes and combinations, found that the improved ST of grafted plants was lower at $25 \mathrm{~mm}$ of $\mathrm{NaCl}$ than at 50 and $75 \mathrm{~mm}$ levels of $\mathrm{NaCl}$.

The higher yield performance constantly observed for 2 years in plants of CB grafted onto 'Arnold' and grown in the presence of $20 \mathrm{~mm}$ of $\mathrm{NaCl}$, compared with non-grafted plants or those grafted on 'Maxifort' and/or 'Armstrong', suggests that the rootstock genotype plays a significant role in the ST mechanisms and highlights the importance of testing the ST of each commercial rootstock before recommending their use in commercial crops. Although all tested rootstocks were interspecific hybrids of $S$. lycopersicum $\times$ $S$. habrochaites, they showed a different behavior, and this may be explained by the fact that different accessions of the same 

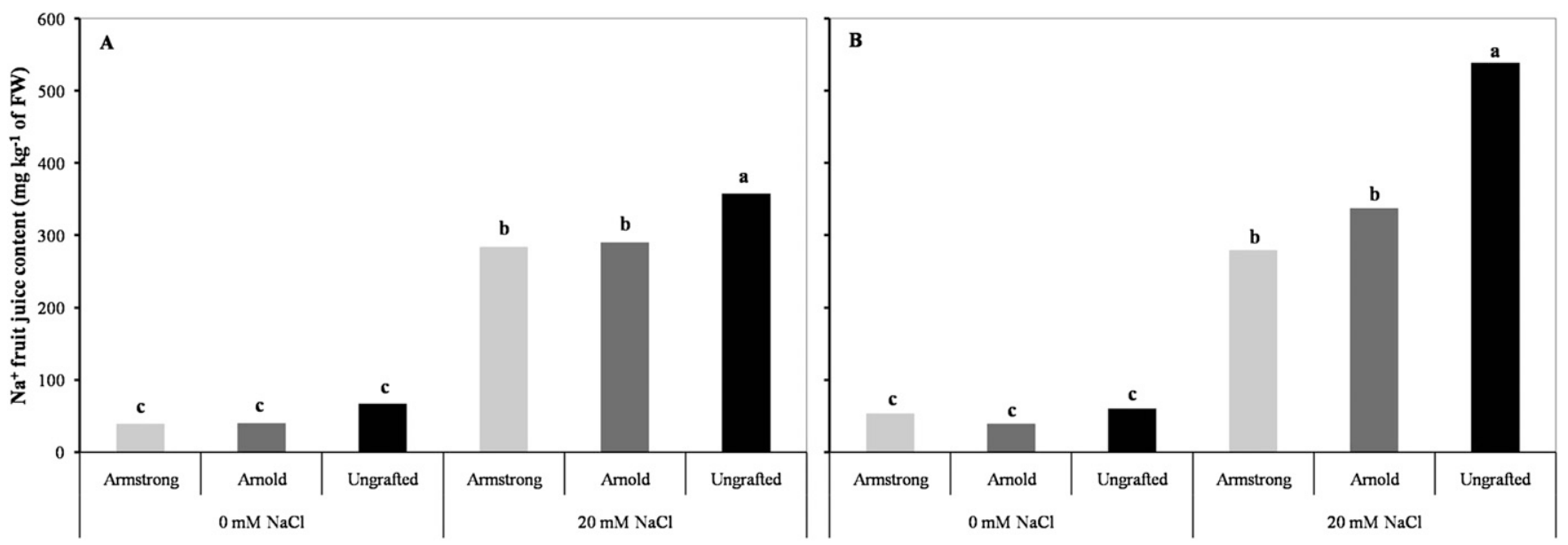

Fig. 5. Effects of salinity level and grafting combinations on the juice $\mathrm{Na}^{+}$content of 'Cuore di Bue' tomato fruits harvested on 8 June 2010 (A) and on 21 June 2010 (B). Different letters indicate significant differences at $P=0.05$ by Duncan's multiple range test.

Table 3. $\mathrm{Na}^{+}, \mathrm{K}^{+}, \mathrm{Mg}^{2+}$, and $\mathrm{Ca}^{2+}$ content and $\mathrm{K}^{+} / \mathrm{Na}^{+}, \mathrm{Mg}^{2+} / \mathrm{Na}^{+}$, and $\mathrm{Ca}^{2+} / \mathrm{Na}^{+}$ratios of different shoot portions of grafted and ungrafted 'Cuore di Bue' tomato plants grown under salt stress conditions $(20 \mathrm{~mm} \mathrm{NaCl})$ in $2010{ }^{z}$

\begin{tabular}{|c|c|c|c|c|c|c|c|c|c|}
\hline \multirow{2}{*}{$\frac{\text { DAT }^{y}}{126}$} & \multirow[b]{2}{*}{ Shoot portion } & \multirow[b]{2}{*}{ Grafting combination } & $\mathrm{Na}^{+}$ & $\mathrm{K}^{+}$ & $\mathrm{Mg}^{2+}$ & $\mathrm{Ca}^{2+}$ & \multirow[b]{2}{*}{$\mathrm{K}^{+} / \mathrm{Na}^{+}$} & \multirow[b]{2}{*}{$\mathrm{Mg}^{2+} / \mathrm{Na}^{+}$} & \multirow[b]{2}{*}{$\mathrm{Ca}^{2+} / \mathrm{Na}^{+}$} \\
\hline & & & \multicolumn{4}{|c|}{$\left(\mathrm{mg} \cdot \mathrm{kg}^{-1}\right.$ of $\left.\mathrm{DM}\right)$} & & & \\
\hline & & Arnold & $6.008 \mathrm{~b}$ & 44.524 & 2.437 & 3.693 & $7.58 \mathrm{a}$ & $0.42 \mathrm{a}$ & $0.64 \mathrm{ab}$ \\
\hline & Significance & & $* *$ & NS & NS & NS & $*$ & * & * \\
\hline \multirow[t]{6}{*}{93} & Plant tips & Armstrong & $15.267 \mathrm{~b}$ & 24.825 & $13.573 \mathrm{a}$ & $54.567 \mathrm{a}$ & $1.63 \mathrm{a}$ & $0.89 \mathrm{a}$ & $3.58 \mathrm{a}$ \\
\hline & & Arnold & $17.741 \mathrm{~b}$ & 25.012 & $13.379 \mathrm{a}$ & $57.699 a$ & $1.41 \mathrm{~b}$ & $0.75 \mathrm{~b}$ & $3.26 \mathrm{a}$ \\
\hline & & Ungrafted & $33.048 \mathrm{a}$ & 25.356 & $11.908 \mathrm{~b}$ & $44.161 \mathrm{~b}$ & $0.78 \mathrm{c}$ & $0.36 \mathrm{c}$ & $1.34 \mathrm{~b}$ \\
\hline & & Arnold & $9.472 \mathrm{a}$ & $29.483 \mathrm{~b}$ & 12.870 & 65.194 & $3.11 \mathrm{~b}$ & 1.36 & $6.88 \mathrm{~b}$ \\
\hline & & Ungrafted & $8.308 \mathrm{~b}$ & $35.188 \mathrm{a}$ & 12.996 & 59.722 & $4.23 \mathrm{a}$ & 1.57 & $7.19 \mathrm{~b}$ \\
\hline & Significance & & $*$ & $*$ & NS & NS & $* *$ & NS & $* *$ \\
\hline \multirow[t]{11}{*}{64} & Upper leaves & Armstrong & $6.610 \mathrm{~b}$ & 55.580 & $10.045 \mathrm{a}$ & $31.054 \mathrm{a}$ & $8.44 \mathrm{a}$ & $1.52 \mathrm{a}$ & $4.71 \mathrm{a}$ \\
\hline & & Arnold & $6.813 \mathrm{~b}$ & 54.036 & $9.940 \mathrm{a}$ & $29.845 \mathrm{a}$ & $7.89 \mathrm{a}$ & $1.45 \mathrm{a}$ & $4.35 \mathrm{a}$ \\
\hline & & Ungrafted & $8.458 \mathrm{a}$ & 43.515 & $7.653 \mathrm{~b}$ & $21.830 \mathrm{~b}$ & $5.14 \mathrm{~b}$ & $0.91 \mathrm{~b}$ & $2.60 \mathrm{~b}$ \\
\hline & Significance & & $*$ & NS & * & $*$ & $*$ & $* *$ & $*$ \\
\hline & & Arnold & $12.587 \mathrm{a}$ & 46.043 & 16.344 & 70.708 & $3.79 \mathrm{~b}$ & 1.34 & 5.82 \\
\hline & & Ungrafted & $8.263 \mathrm{~b}$ & 48.492 & 13.488 & 60.744 & $5.89 \mathrm{a}$ & 1.63 & 7.34 \\
\hline & Significance & & * & NS & NS & NS & $*$ & NS & NS \\
\hline & Stem & Armstrong & 7.642 & 72.069 & 5.949 & 14.432 & 9.46 & 0.80 & 1.96 \\
\hline & & Arnold & 8.961 & 81.374 & 5.626 & 14.684 & 8.95 & 0.63 & 1.68 \\
\hline & & Ungrafted & 6.213 & 54.563 & 4.353 & 12.069 & 8.94 & 0.72 & 2.04 \\
\hline & Significance & & NS & NS & NS & NS & NS & NS & NS \\
\hline
\end{tabular}

${ }^{2}$ Means followed by different letters within a column for each shoot portion are significantly different at $P=0.05$ by Duncan's multiple range test.

${ }^{\mathrm{y}}$ Days after transplanting.

Ns, *,**,*** Nonsignificant or significant at $P \leq 0.05,0.01$, or 0.001 , respectively.

$\mathrm{DM}=$ dry matter.

species (S. lycopersicum and S. habrochaites), used to develop interspecific hybrids, may have different levels of ST (Bolarin et al., 1991; Öztekin and Tüzel, 2011).

Fruit quality and $\mathrm{Na}^{+}$content. The similar fruit quality observed in both experiments between grafted and ungrafted plants, either under standard or SS conditions, corroborates previous findings (Di Gioia et al., 2010; Fabre et al., 2011; Savvas et al., 2011). Moreover, the TSS:TA ratio, whose values ranged between 10:1 and 18:1 (Table 2), confirmed the good balance between sweetness and sourness and the high-quality profile achieved by $\mathrm{CB}$ fruits regardless of the grafting combination used.

The lower fruit juice $\mathrm{Na}^{+}$content, consistently observed in $\mathrm{CB}$ grafted plants grown under SS conditions, in all harvesting dates and both experiments, with respect to ungrafted plants (Figs. 3 and 4), represents an added value and suggests that grafting may be a good strategy for producing tomato under SS conditions by also taking advantage of SS effects on quality without reducing but actually increasing the fruit nutritional value.
Shoot $\mathrm{Na}^{+}$partitioning and rootstock role in ST mechanisms. The lower $\mathrm{Na}^{+}$content observed under SS conditions $(20 \mathrm{~mm}$ of $\mathrm{NaCl}$ ) in upper leaves, plant tips, and fruits of $\mathrm{CB}$ grafted plants, compared with ungrafted ones (Table 3), may suggest that the grafting itself can enhance the plant ST by simply reducing the $\mathrm{Na}^{+}$xylematic transport from root to shoot, preventing its accumulation at toxic levels (Estañ et al., 2005). However, it does not seem a likely explanation considering that plants grafted onto 'Arnold' showed a $\mathrm{Na}^{+}$content in bottom 
leaves significantly higher than the one observed in the same portion of ungrafted plants (Table 3). Instead, the present results suggest that the rootstocks, and particularly 'Arnold', can modulate $\mathrm{Na}^{+}$accumulation and partitioning within the shoot (Albacete et al., 2009), probably by removing $\mathrm{Na}^{+}$from the solution moving toward younger leaves through the inclusion in older and less active leaves at the bottom of the plant (Zhang and Blumwald, 2001), enhancing at the same time $\mathrm{Na}^{+}$exclusion from younger leaves and shoot tips (Shi et al., 2002) and its redirection toward the bottom of the shoot.

Sodium recirculation and partitioning within the shoot, with protection of younger leaves and accumulation in older ones, are considered to be crucial for ST (Shannon, 1997; Tester and Davenport, 2003) and they have been observed in several monocot and dicot species, including tomato (Ghanem et al., 2009; Maggio et al., 2007) and especially some salt-tolerant accessions of wild tomato species (Pérez-Alfocea et al., 2000). In this regard, it is noteworthy that tested rootstocks are interspecific hybrids of $S$. lycopersicum and $S$. habrochaites and that, unlike $S$. lycopersicum cultivated species, which usually tend to exclude toxic ions (Foolad, 2004; Martinez-Rodriguez et al., 2008; Tal and Shannon, 1983), the ST of most wild tomato species, including some accessions of $S$. habrochaites (formerly $L$. hirsutum), is mainly attributed to their $\mathrm{Na}^{+}$ accumulation capacity in leaves (Albacete et al., 2009; Bolarin et al., 1991; PérezAlfocea et al., 2000). In accordance with other research, the present study suggests that the plant ST is more closely correlated to the ability to regulate the $\mathrm{Na}^{+}$concentration in leaf tissues than to the $\mathrm{Na}^{+}$concentration itself (Sacher et al., 1983), and $\mathrm{Na}^{+}$partitioning in young and mature leaves represents an important part of such regulation (Shannon, 1997; Shannon et al., 1987).

The relevance of the shoot $\mathrm{Na}^{+}$partitioning and recirculation in the mechanism of ST has been also demonstrated by Olías et al. (2009a, 2009b) and Zhang and Blumwald (2001) who, using transgenic tomato plants, highlighted the considerable role of vacuolar and plasma membrane $\mathrm{Na}^{+} / \mathrm{H}^{+}$antiporter in maintaining a low $\mathrm{Na}^{+}$concentration and a high $\mathrm{K}^{+} / \mathrm{Na}^{+}$ratio in the plant cytosol. Moreover, Olías et al. (2009a, 2009b) demonstrated the existence of a more complex network of transport processes, named the Salt Overlay Sensitive signaling pathway, regulating the $\mathrm{Na}^{+}$uptake, extrusion through the plasma membrane, compartmentation into cell vacuoles, long-distance $\mathrm{Na}^{+}$transportation from roots to shoots, and recirculation through the plant organs.

The higher $\mathrm{K}^{+} / \mathrm{Na}^{+}, \mathrm{Mg}^{2+} / \mathrm{Na}^{+}$, and $\mathrm{Ca}^{2+} / \mathrm{Na}^{+}$ ratios observed under SS conditions in fruits, plant tips, and upper leaves of grafted plants compared with ungrafted ones (Table 3 ), in agreement with previous findings (Albacete et al., 2009; Santa-Cruz et al., 2002; Savvas et al., 2011), provided further evidence of the ability of grafted plants to avoid or at least limit ion imbalances under SS conditions. However, the lower $\mathrm{K}^{+} / \mathrm{Na}^{+}$ratio observed in bottom leaves of grafted plants compared with ungrafted ones indicates that the maintenance of the ion homeostasis was mainly the result of the ability of grafted plants to regulate $\mathrm{Na}^{+}, \mathrm{K}^{+}, \mathrm{Mg}^{2+}$, and $\mathrm{Ca}^{2+}$ partitioning within the shoot rather than to an increased $\mathrm{K}^{+}, \mathrm{Mg}^{2+}$, and $\mathrm{Ca}^{2+}$ uptake capacity of the rootstock.

\section{Conclusions}

Salinity stress level consistently affected yield and fruit quality performance of grafted and ungrafted plants. Under no SS conditions, plants grafted onto 'Maxifort' and 'Armstrong' provided the best yield performance. In the presence of moderate SS conditions $(20 \mathrm{~mm}$ of $\mathrm{NaCl})$, the rootstock 'Arnold' showed a particular ability to modulate shoot $\mathrm{Na}^{+}$partitioning and assured the maintenance of higher $\mathrm{K}^{+} / \mathrm{Na}^{+}, \mathrm{Mg}^{2+} / \mathrm{Na}^{+}$, and $\mathrm{Ca}^{2+} / \mathrm{Na}^{+}$ratios in fruits and developing leaves, thereby enhancing the yield performance of 'Cuore di Bue', yet at higher SS levels ( $40 \mathrm{~mm}$ of $\mathrm{NaCl}$ ), vegetable grafting did not enhance the crop ST.

Such results suggest that vegetable grafting, with the use of selected rootstock genotypes, could be a good strategy to increase the ST and yield performance of valuable but salt-sensitive tomato cultivars like Cuore di Bue and other heirloom tomatoes, especially under moderate SS level.

Shoot $\mathrm{Na}^{+}$partitioning, with protection of younger and most active leaves and accumulation in older ones, represents a key aspect of the mechanism of ST in tomato grafted plants. However, such mechanism of ST may work only in the presence of moderate SS levels $(20 \mathrm{~mm}$ of $\mathrm{NaCl})$.

Finally, the use of grafting does not reduce the fruit organoleptic quality and under SS conditions, it may actually increase the tomato nutritional value by limiting fruit $\mathrm{Na}^{+}$ accumulation.

\section{Literature Cited}

Albacete, A., C. Martínez-Andújar, M.E. Ghanem, M. Acosta, J. Sánchez-Bravo, M.J. Asins, J. Cuartero, S. Lutts, I.C. Dodd, and F. PérezAlfocea. 2009. Rootstock-mediated changes in xylem ionic and hormonal status are correlated with delayed leaf senescence, and increased leaf area and crop productivity in salinized tomato. Plant Cell Environ. 32:928-938.

Barrett, C.E., X. Zhao, and R. McSorley. 2012. Grafting for root-knot nematode control and yield improvement in organic heirloom tomato production. HortScience 47:614-620.

Bolarin, M., F. Fernandez, V. Cruz, and J. Cuartero. 1991. Salinity tolerance in four wild tomato species using vegetative yield-salinity response curves. J. Amer. Soc. Hort. Sci. 116 : 286-290.

Chen, G., X. Fu, S.H. Lips, and M. Sagi. 2003. Control of plant growth resides in the shoot, and not in the root, in reciprocal grafts of flacca and wild-type tomato (Lycopersicon esculentum), in the presence and absence of salinity stress. Plant Soil 256:205-215.
Colla, G., Y. Rouphael, M. Cardarelli, and E. Rea. 2006. Effect of salinity on yield, fruit quality, leaf gas exchange, and mineral composition of grafted watermelon plants. HortScience 41:622-627.

Colla, G., Y. Rouphael, C. Leonardi, and Z. Bie. 2010. Role of grafting in vegetable crops grown under saline conditions. Sci. Hort. 127:147155 .

Cuartero, J. and R. Fernandez-Muñoz. 1999. Tomato and salinity. Sci. Hort. 78:83-125.

Davis, A.R., P. Perkins-Veazie, R. Hassell, A. Levi, S.R. King, and X. Zhang. 2008. Grafting effects on vegetable quality. HortScience 43: 1670-1672.

Di Gioia, F., F. Serio, D. Buttaro, O. Ayala, and P. Santamaria. 2010. Influence of rootstock on vegetative growth, fruit yield and quality in 'Cuore di Bue', an heirloom tomato. J. Hort. Sci. Biotechnol. 85:477-482.

Edelstein, M., Z. Plaut, and M. Ben-Hur. 2011. Sodium and chloride exclusion and retention by non-grafted and grafted melon and Cucurbita plants. J. Expt. Bot. 62:177-184.

Estañ, M.T., M.M. Martinez-Rodriguez, F. PerezAlfocea, T.J. Flowers, and M.C. Bolarin. 2005. Grafting raises the salt tolerance of tomato through limiting the transport of sodium and chloride to the shoot. J. Expt. Bot. 56:703-712.

Estañ, M.T., I. Villalta, M.C. Bolarin, E.A. Carbonell, and M.J. Asins. 2009. Identification of fruit yield loci controlling the salt tolerance conferred by solanum rootstocks. Theor. Appl. Genet. 118: 305-312.

Fabre, R., M. Duval, and B. Jeannequin. 2011. Effect of the salinity on the organoleptic quality and yield of early-grown soilless grafted tomatoes under heated glasshouses in the south of France. Cah. Agr. 20:266-273.

Fernández-García, N., V. Martínez, and M. Carvajal. 2004. Effect of salinity on growth, mineral composition, and water relations of grafted tomato plants. J. Plant Nutr. Soil Sci. 167: 616-622.

Foolad, M.R. 2004. Recent advances of salt tolerance in tomato. Plant Cell. Tiss. Org. 76:101-119.

Ghanem, M.E., I. Hichri, A.C. Smigocki, A. Albacete, M.-L. Fauconnier, E. Diatloff, C. Martínez-Andújar, M. Acosta, J. SanchezBravo, S. Lutts, I.C. Dodd, and F. PérezAlfocea. 2011. Root-targeted biotechnology to mediate hormonal signaling and improve crop stress tolerance. Plant Cell Rpt. 30:807823.

Ghanem, M.E., J. van Elteren, A. Albacete, M. Quinet, C. Martínez-Andújar, J.M. Kinet, F. Pérez-Alfocea, and S. Lutts. 2009. Impact of salinity on early reproductive physiology of tomato (Solanum lycopersicum) in relation to a heterogeneous distribution of toxic ions in flower organs. Funct. Plant Biol. 36:125-136.

Giuffrida, F., M. Martorana, and C. Leonardi. 2009. How sodium chloride concentration in the nutrient solution influences mineral composition of tomato and fruits. HortScience 44: 707-711.

Guan, W., X. Zhao, R. Hassell, and J. Thies. 2012. Defense mechanisms involved in disease resistance of grafted vegetables. HortScience 47:164-170.

Karppanen, H. and E. Marvaala. 2006. Sodium intake and hypertension. Prog. Cardiovasc. Dis. 49:59-79.

Khah, E.M., E. Kakava, A. Mavromatis, D. Chachalis, and C. Goulas. 2006. Effect of grafting on growth and yield of tomato ( $\mathrm{LyCO}-$ persicon esculentum Mill.) in greenhouse and open-field. J. Appl. Hort. 8:3-7. 
King, S.R., A.R. Davis, W. Liu, and A. Levi. 2008. Grafting for disease resistance. HortScience 43:1673-1676.

King, S.R., A.R. Davis, X. Zhang, and K. Crosby. 2010. Genetics, breeding and selection of rootstocks for Solanaceae and Cucurbitaceae. Sci. Hort. 127:106-111.

Kubota, C., M.A. McClure, N. Kokalis-Burelle, M.G. Bausher, and E.N. Rosskopf. 2008. Vegetable grafting: History, use, and current technology status in North America. HortScience 43:1664-1669.

Lee, J.M., C. Kubota, S.J. Tsao, Z. Bie, P.H. Echevarria, L. Morra, and M. Oda. 2010. Current status of vegetable grafting: Diffusion, grafting techniques, automation. Sci. Hort. 127: 93-105.

Leonardi, C. and F. Giuffrida. 2006. Variation of plant growth and macronutrient uptake in grafted tomatoes and eggplants on three different rootstocks. Eur. J. Hort. Sci. 71:97-101.

Maggio, A., G. Raimondi, A. Martino, and S. De Pascale. 2007. Salt stress response in tomato beyond the salinity tolerance threshold. Environ. Exp. Bot. 59:276-282.

Martinez-Rodriguez, M.M., M.T. Estan, E. Moyano, J.O. Garcia-Abellan, F.B. Flores, J.F. Campos, M.J. Al-Azzawi, T.J. Flowers, and M.C. Bolarin. 2008. The effectiveness of grafting to improve salt tolerance in tomato when an 'excluder' genotype is used as scion. Environ. Exp. Bot. 63:392-401.

Olías, R., Z. Eljakaoui, J. Li, P.A. De Morales, M.C. Marín-Manzano, J.M. Pardo, and A Belver. 2009a. The plasma membrane $\mathrm{Na}^{+} / \mathrm{H}^{+}$ antiporter SOS1 is essential for salt tolerance in tomato and affects the partitioning of $\mathrm{Na}^{+}$ between plant organs. Plant Cell Environ. 32:904-916.
Olías, R., Z. Eljakaoui, J.M. Pardo, and A. Belver. 2009b. The $\mathrm{Na}^{+} / \mathrm{H}^{+}$exchanger SOS1 controls extrusion and distribution of $\mathrm{Na}^{+}$in tomato plants under salinity conditions. Plant Signal. Behav. 4:973-976.

Öztekin, G.B. and Y. Tüzel. 2011. Salinity response of some tomato rootstocks at seedling stage. Afr. J. Agr. Res. 6:4726-4735.

Pérez-Alfocea, F., M.E. Balibrea, J.J. Alarcon, and M.C. Bolarin. 2000. Composition of xylem and phloem exudates in relation to the salt-tolerance of domestic and wild tomato species. J. Plant Physiol. 156:367374.

Pérez-Alfocea, F., M.T. Estañ, M. Caro, and M.C Bolarín. 1993. Response of tomato cultivars to salinity. Plant Soil 150:203-211.

Rouphael, Y., D. Schwarz, A. Krumbein, and G. Colla. 2010. Impact of grafting on product quality of fruit vegetable crops. Sci. Hort. 127: 172-179.

Rozema, J. and T. Flowers. 2008. Crops for a salinized world. Science 322:1478-1480.

Sacher, R.F., R.C. Staples, and R.W. Robinson. 1983. Ion regulation and response of tomato to sodium chloride: A homeostatic system. J. Amer. Soc. Hort. Sci. 108:566-569.

Santa-Cruz, A., M.M. Martínez-Rodríguez, F. Perez-Alfocea, R. Romero-Aranda, and M.C. Bolarin. 2002. The rootstock effect on the tomato salinity response depends on the shoot genotype. Plant Sci. 162:825-831.

Savvas, D., G. Colla, Y. Rouphael, and D. Schwarz. 2010. Amelioration of heavy metal and nutrient stress in fruit vegetables by grafting. Sci. Hort. 127:156-161.

Savvas, D., A. Savva, G. Ntatsi, A. Ropokis, I Karapanos, A. Krumbein, and A. Olympios. 2011. Effects of three commercial rootstocks on mineral nutrition, fruit yield, and quality of salinized tomato. J. Plant Nutr. Soil Sci. 174:154-162.

Schwarz, D., Y. Rouphael, G. Colla, and J.H. Venema. 2010. Grafting as a tool to improve tolerance of vegetables to abiotic stresses: Thermal stress, water stress and organic pollutants. Sci. Hort. 127:162-171.

Shannon, M.C. 1997. Adaptation of plants to salinity. Adv. Agron. 60:75-120.

Shannon, M.C., J.W. Gronwald, and M. Tal. 1987. Effects of salinity on growth and accumulation of inorganic ions in cultivated and wild tomato species. J. Amer. Soc. Hort. Sci. 112: 416-423.

Shi, H., F.J. Quintero, J.M. Pardo, and J.K. Zhu. 2002. The putative plasma membrane $\mathrm{Na}^{+} / \mathrm{H}^{+}$antiporter SOS1 controls long-distance $\mathrm{Na}^{+}$transport in plants. Plant Cell 14:465477 .

Tal, M. and M.C. Shannon. 1983. Salt tolerance in the wild relatives of the cultivated tomato: Responses of Lycopersicon esculentum, $L$. cheesmani, L. peruvianum, Solanum pennelli, and F1 hybrids to high salinity. Aust. J. Plant Physiol. 10:109-117.

Tanji, K.K. and N.C. Kielen. 2002. Agricultural drainage water management in arid and semi-arid areas. FAO irrigation and drainage paper 61. FAO, Food and Agriculture Organization of the United Nations, Rome, Italy.

Tester, M. and R. Davenport. 2003. $\mathrm{Na}^{+}$tolerance and $\mathrm{Na}^{+}$transport in higher plants. Ann. Bot. (Lond.) 91:503-527.

Zhang, H.X. and E. Blumwald. 2001. Transgenic salt-tolerant tomato plants accumulate salt in foliage but not in fruit. Nat. Biotechnol. 19:765-768 